\title{
A TEORIA DA IMPREVISÃO NOS CONTRATOS ADMINISTRATIVOS
}

\section{Anderson Laurentino de Medeiros}

Aluno da FA7, orientado pelo Prof. Dr. João Luís Nogueira Matias anderson_laurentino@yahoo.com.br

Sumário: 1) $\mathrm{O}$ contrato e a sociedade. 2) Conceituação e a função social dos contratos. 3) Normas incidentes na relação contratual. 4) Da cláusula rebus sic stantibus à Teoria da Imprevisão. 5) Revisão contratual. Considerações finais.

Resumo: O Estado, quando figura como sujeito de uma relação contratual, possui certas prerrogativas, que são inerentes à sua própria condição de supremacia. Dessa forma, os contratos regidos por normas de Direito Público deverão ser analisados com mais cautela, já que, nessa modalidade contratual, não poderão ser livremente utilizados determinados institutos largamente aplicados naqueles pactos celebrados entre particulares, e regidos por normas de caráter privado. Os princípios norteadores dos contratos tipicamente privados, como, por exemplo, o da obrigatoriedade do cumprimento dos contratos e o da autonomia da vontade, deverão sofrer certa mitigação, tendo em vista os princípios que regem as atividades da Administração Pública, tais como o princípio da supremacia do interesse público sobre o interesse particular, e, também, o princípio da continuidade do serviço público. O interesse público deve sempre prevalecer sobre o interesse do particular, servindo de fundamento para reger as relações entre o ente público e terceiros.

Palavras-chave: Administração Pública. Supremacia. Teoria da Imprevisão. Contratos administrativos.

\section{CONTRATO E A SOCIEDADE}

Não se pode fixar exatamente uma data específica para o surgimento dos contratos, mas pode-se afirmar que sua ocorrência se confunde com a própria evolução moral da humanidade, sendo qualquer estipulação de uma data ou período predefinido carecedora de validade científica (Gagliano e Pamplona Filho, 2006).

Mesmo nas épocas mais remotas, onde sua existência já era conhecida por todos, os contratos, assim como todos os atos jurídicos, já possuíam um caráter rigoroso e sacramental, momento em que o princípio da obrigatoriedade 
dos contratos, conhecido pela expressão pacta sunt servanda, começa a ganhar contornos absolutos.

A sociedade atual é caracterizada por ser de massa, onde as pessoas são praticamente obrigadas a contratar. Isso leva ao afastamento daquela concepção que o contrato representaria uma exteriorização livre da vontade. Essa manifestação volitiva se resumiria, basicamente, em contratar ou não, como ocorre nos chamados contratos de adesão.

Cabe, assim, ao Estado intervir nas relações negociais sempre que os princípios que regem o negócio jurídico contratual forem desrespeitados.

Enfim, é indiscutível a importância dos contratos no mundo atual, sendo uma peça essencial no mundo capitalista, funcionando como um peculiar mecanismo para a circulação de riqueza do mundo moderno. Não se pode conceber a vida em sociedade sem a figura contratual, já que toda a vida do homem é acompanhada por ele.

\section{CONCEITUAÇÃO E A FUNÇÃO SOCIAL DOS CONTRATOS}

Importante salientar que o Código Civil brasileiro não traz qualquer definição de contrato, o que é digno de aplausos, tendo em vista que não é função precípua de um Código tratar de definições, deixando isso para os doutrinadores.

Diferentemente do ordenamento jurídico cível pátrio, o Código Civil Francês traz disposição expressa a respeito do que seja o contrato. Assim, o Code Civil dispõe, em seu art.1101, que "Le contrat est une convention par laqualle une ou plusieurs s'obligent envers une ou plusieurs autres a donner, a faire ou a ne pas faire quelque chose" ". Ou seja, "O contrato é uma convenção pela qual uma ou várias pessoas obrigam-se para com um ou vários outros a dar, a fazer ou a não fazer algo" [traduziu-se].

O Código Civil de la República Argentina igualmente se preocupou com a definição dos contratos, e traz em seu art. 1137 tal definição. Assim, aduz o artigo supramencionado que "Hay contrato cuando varias personas se ponen de acuerdo sobre una declaración de voluntad común, destinada a reglar sus derechos" 2. Isto é, "Haverá contrato quando várias pessoas se põem de acordo sobre uma declaração de vontade comum, destinada a regular seus direitos" [traduziu-se].

Outro ordenamento jurídico que buscou incluir no bojo de suas normas uma definição da figura contratual foi o Código Civil Italiano. O Códice Civile Italiano, em seu art. 1321, aduz que "Il contratto è l'accordo di due ou più parti per costituire, regolare o estinguere tra loro un rapporto giuridico patrimoniale", . Ou seja, "O

\footnotetext{
${ }^{1}$ Disponível em: $<$ http://www.adagio.com.fr/consomed/FRCO0444.HTM $>$. Acesso em: 17 jul. 2007.

${ }^{2}$ Disponível em: $<$ http://www.redetel.gov.ar $>$. Acesso em: 17 jul. 2007.

${ }^{3}$ Disponível em: $<$ http://www.direzioneamministrativa.unile.it $>$. Acesso em: 19 jul. 2007.
} 
contrato é o acordo de duas ou mais partes para constituir, regular ou extinguir entre elas uma relação jurídica patrimonial" [traduziu-se].

Para Monteiro (2003, p.5), o contrato seria um "acordo de vontades que tem por fim criar, modificar ou extinguir um direito". Dessa forma, a natureza constitutiva dos contratos aqui constatada é clara, e, em se tratando de um negócio jurídico, requer para sua validade a capacidade dos agentes, que o objeto seja lícito, possível, determinado ou determinável, e, ainda, que sua forma seja prescrita ou não defesa em lei.

Apesar do Código Civil não trazer uma disposição expressa daquilo que venha ser um contrato, procura limitar a atividade de contratar à sua função social. É nesse sentido que dispõe o art.421 do Código Civil: "A liberdade de contratar será exercida em razão e nos limites da função social do contrato." [Destacouse]. Diante do que se expôs do mencionado artigo, pode-se constatar que existe uma garantia plena da liberdade de se contratar, desde que, contudo, haja o estrito respeito aos limites impostos pela função social dos contratos.

O sentido social que é atribuído aos contratos no atual diploma cível é uma das suas características mais marcantes, o que denota a prevalência dos valores coletivos em detrimento dos individuais, sem, contudo, suprimir o valor fundamental da pessoa humana. Dessa forma, aquela concepção individualista que prevalecia no Código Civil de 1916 vai ficando ultrapassada, não mais fazendo parte da nossa realidade social (Gonçalves, 2004).

Importante trazer o ensinamento de Pereira que, no que atine à função social dos contratos, preconiza:

A função social do contrato é um princípio moderno que vem a se agregar aos princípios clássicos do contrato, que são o da autonomia da vontade, da força obrigatória, da intangibilidade do seu conteúdo e da relatividade dos seus efeitos. Como princípio novo ele não se limita a se justapor aos demais, antes pelo contrário vem desafiá-los e em certas situações impedir que prevaleçam, diante do interesse social. (2004, p.14)

Nessa mesma linha, Santos (2002, p.29) expõe que:

[....] o contrato não pode mais ser entendido como mera relação individual. É preciso atentar para os seus efeitos sociais, econômicos, ambientais e até mesmo culturais. Em outras palavras, tutelar o contrato unicamente para garantir a equidade das relações negociais em nada se aproxima da idéia de função social. O contrato somente terá uma função social uma função pela sociedade quando for dever dos contratantes atentar para as exigências do bem comum, para o bem geral. Acima do interesse em que o contrato seja respeitado, acima do interesse em que a declaração seja cumprida fielmente e acima da noção de equilíbrio 
meramente contratual, há interesse de que o contrato seja socialmente benéfico, ou, pelo menos, que não traga prejuízos à sociedade em suma, que o contrato seja socialmente justo.

Após o abandono daquela concepção estritamente individualista e, acima de tudo, materialista, adotada pelo ordenamento cível anterior, reflexo da sociedade patriarcal e conservadora que dirigia a nação naquele momento, o nosso Código Civil atual, com sustentação na dignidade da pessoa humana, e na superioridade do interesse social em detrimento de interesses particulares, busca na função social dos contratos um norteador da conduta humana, impedindo que qualquer estipulação contratual venha a suprimir direitos constitucionalmente protegidos.

\section{NORMAS INCIDENTES NA RELAÇÃO CONTRATUAL}

Os contratos poderão ser regidos por normas de naturezas jurídicas distintas, dependendo daqueles que figurarem nos pólos da relação negocial. Dessa maneira, sendo a avença composta apenas por particulares, o negócio jurídico será regido por normas de Direito Privado. Agora, se em um dos pólos do pacto estiver o Estado, agindo com todas as características que lhe são inerentes, ter-se-á uma avença regida, preponderantemente, por normas de Direito Público, de caráter cogente e observância obrigatória.

\subsection{Contratos REgIDOS POR NORMAS DE DIREITO PRIVADO}

No campo contratual, as pessoas são inteiramente livres para disciplinarem seus interesses mediante acordo de vontades. Tal liberdade inclui o direito de se contratar, com quem contratar e sobre o que contratar. Há a liberdade de estipular desde o conteúdo contratual, até mesmo a vontade de não contratar. É a expressão máxima do princípio da autonomia da vontade (Gonçalves, 2004).

Assim, importante se trazer à balia o que ensina Venosa, quando aduz:

Essa liberdade de contratar pode ser vista sob dois aspectos. Pelo prisma da liberdade propriamente dita de contratar ou não, estabelecendo-se o conteúdo do contrato, ou pelo prisma da escolha da modalidade do contrato. (2004, p.389).

A liberdade, inerente à própria autonomia da vontade, pode ser determinada pela presença de três elementos básicos: 1) a própria liberdade de contratar, que é aquela onde a pessoa decide se quer ou não pactuar com outrem, não podendo ser forçado a celebrar um negócio jurídico, ressalvados obviamente aqueles casos de contratação obrigatória; 2) a liberdade de com quem contratar, que ocorre 
mediante a escolha de com quem celebrar determinada avença; e 3) a liberdade de estabelecimento do conteúdo contratual, que se dá quando as partes decidem a respeito daquilo que se vai contratar.

Quanto à liberdade contratual, importante ressaltar que tal princípio não é absoluto. A própria evolução da sociedade nos impõe a celebração das mais diversas formas de contrato, o que relativizaria em parte a liberdade de se contratar ou não. A escolha da parte com quem se vai contratar também sofre restrições, já que quando se tratar da Administração Pública, cerne do presente estudo, há a predominância de certas prerrogativas em seu benefício, como se verá em momento oportuno. E, por fim, a estipulação do conteúdo contratual não se faz por mero alvedrio dos convenentes, pois se deve buscar sempre preservar a boa-fé e os limites impostos pela função social do contrato.

Celebrado o acordo, e, atendidos todos os requisitos necessários à sua validade, o ordenamento jurídico deve proporcionar meios para que esse negócio celebrado seja cumprido como se suas cláusulas fossem preceitos legais imperativos. Dessa forma, o contrato considerado válido e eficaz faz lei entre as partes. Isso é corolário direto da antiga expressão: pacta sunt servanda.

Os pactuantes, assim, ficam submetidos àquilo que fora contratado, devendo cumprir com suas obrigações na forma que fora estipulado. Por isso que nas relações contratuais regidas por normas de Direito Privado, prevalece, quase que com conotação absoluta, a obrigatoriedade do cumprimento da avença.

Assim como ocorre com todos os outros princípios do nosso ordenamento jurídico, o princípio da obrigatoriedade dos contratos não pode ser encarado de forma absoluta. Não se pode atribuir aos contratos a característica de imutáveis ou intangíveis, o que poderia claramente se tornar um forte instrumento de opressão econômica (Gagliano e Pamplona Filho, 2006). E uma das formas de suavizar os efeitos do princípio em estudo é justamente mediante a utilização de instrumentos que permitam, por exemplo, uma revisão de um contrato que teve seus termos alterados pela superveniência de algum evento imprevisto e imprevisível. Isso se dá através da aplicação da Teoria da Imprevisão, objeto desse estudo.

Mudanças imprevistas, portanto, que ocorram durante a execução do contrato, e que acarretem para uma das partes uma excessiva onerosidade, justificarão a revisão contratual com o objetivo de restabelecer a equação econômico-financeira da avença.

Da maneira que é garantido às partes a possibilidade de contratar, é também reservado o direito de escolha do conteúdo contratual, segundo os interesses dos convenentes. Agora, após a conclusão do pacto, o mesmo ordenamento jurídico que tem o condão de garantir a possibilidade de se contratar, estipulando-se ainda os termos da avença, tem a força de obrigar os participantes desse negócio jurídico a cumprirem com o que foi acordado, nos estritos limites do contrato. Uma vez respeitados os ditames legais, não podem mais as partes se escusarem 
das conseqüências que advêm do contrato, assumindo todos os riscos inerentes à pactuação. Às partes, não existe mais nem a possibilidade de alteração unilateral do conteúdo da avença, salvo, obviamente, com a anuência da parte adversa. Não cabe, também, nem ao juiz, na figura de representante do Estado, se preocupar, por exemplo, com a severidade das cláusulas aceitas.

\subsection{Contratos Regidos POR NORMAS de direito PÚBlico}

Assim como aos particulares é atribuído o poder de conjugar suas vontades com o intuito de celebrar um negócio jurídico, com o Estado a situação não é diferente. Sendo pessoa jurídica e, portanto, apta a adquirir direitos e contrair obrigações, possui todos os elementos necessários que lhe permitem figurar como sujeito de uma relação contratual.

Contratos da Administração seria o gênero, do qual fazem parte os contratos privados da Administração Pública, e os contratos públicos, ditos administrativos. Os contratos privados seriam aqueles regulados por normas de direito privado, onde o Estado atua como se fosse um particular na relação jurídica negocial. Aqui, a Administração Pública atua no mesmo plano jurídico da outra parte, não lhe sendo atribuída qualquer vantagem especial. Um exemplo típico dessa modalidade contratual é o contrato de compra e venda firmado pelo Ente Público, na aquisição, por exemplo, de material de expediente. Por sua vez, os contratos administrativos, embora constituam também uma espécie do gênero contratos da Administração, são regulados por normas diferentes, de caráter cogente. Aqui, há a incidência de normas especiais de Direito Público, só sendo aplicadas as normas de Direito Privado de forma supletiva.

Nas precisas palavras de Carvalho Filho (2006, p.152), contrato administrativo seria um "ajuste firmado entre a Administração pública e um particular, regulado basicamente pelo interesse público, e tendo por objeto uma atividade que, de alguma forma, traduza interesse público". A partir dessa conceituação se pode extrair o entendimento no sentido de que, para um contrato ser considerado administrativo, não basta que em um dos pólos figure como sujeito contratual o Estado. Unido ao elemento subjetivo, destaca-se o objetivo, oriundo do fato que o contrato administrativo deve ter como objetivo maior a realização de um interesse público. Logo, o que vai diferenciar efetivamente os contratos administrativos das demais modalidades contratuais é justamente o regime jurídico dessa relação negocial, ou seja, é o conjunto de regras de direito que regulam essa relação jurídica, efetivada, aqui, pela realização do interesse público.

A Administração Pública, em todas as suas atividades, é norteada por princípios que regulamentam as suas condutas, não podendo de forma alguma se esquivar da estrita obediência aos mesmos. Esses princípios podem ser 
encontrados, inclusive, na Constituição Federal de 1988, que expressamente diz quais são esses princípios a que o ente público deve submeter seus atos. Veja:

Art.37. AAdministração Pública direta e indireta de qualquer dos Poderes da União, dos Estados, do Distrito Federal e dos Municípios obedecerá aos princípios da legalidade, impessoalidade, moralidade, publicidade, e eficiência e, também ao seguinte: [Destaques do autor]

Destarte, os contratos administrativos também devem ser submetidos a esses princípios, que, vale salientar, não são os únicos a serem observados, já que existem princípios não expressos que também devem ser invocados, tais como: o da supremacia do interesse público sobre o interesse particular, o da continuidade do serviço público, dentre outros.

\subsubsection{A PRESENÇA DAS CHAMADAS CLÁUSULAS EXORBITANTES}

A presença das chamadas cláusulas exorbitantes é uma das principais características dos contratos administrativos. As cláusulas exorbitantes são aquelas que extrapolam, que excedem, que ultrapassam o padrão comum dos contratos em geral, a fim de consignar uma vantagem para a Administração Pública. Referem-se a certas prerrogativas da Administração que a colocam em situação de superioridade em relação ao particular contratado. Se essas cláusulas estivessem previstas em um contrato regido pelo direito privado, seriam cláusulas abusivas, ilícitas e, portanto, inválidas.

Pode-se identificá-las no art. 58 da Lei Federal n. ${ }^{\circ}$ 8.666/93, abaixo colacionado ipsis litteris:

Art.58. O regime jurídico dos contratos administrativos instituído por essa Lei confere à Administração, em relação à eles, a prerrogativa de:

I. modificá-los, unilateralmente, para melhor adequação às finalidades de interesse público, respeitados os interesses do contratado;

II. rescindi-los, unilateralmente, nos casos especificados no inciso I do art.79 desta Lei;

III. fiscalizar-lhes a execução;

IV. aplicar sanções motivadas pela inexecução total ou parcial do ajuste;

V. nos casos de serviços essenciais, ocupar provisoriamente bens móveis, imóveis, pessoal e serviços vinculados ao objeto do contrato, na hipótese da necessidade de acautelar apuração administrativa de faltas contratuais pelo contratado, bem como na hipótese de rescisão do contrato administrativo.

$\S 1^{\circ}$ As cláusulas econômico-financeiras e monetárias dos contratos administrativos não poderão ser alteradas sem prévia concordância do contratado. 
$\S 2^{\circ} \mathrm{Na}$ hipótese do inciso I deste artigo, as cláusulas econômicofinanceiras do contrato deverão ser revistas para que se mantenha o equilíbrio contratual. [Grifos do autor]

Por fim, vale ressaltar, que o particular que contrata com a Administração Pública não se encontra completamente desamparado. O próprio ordenamento jurídico resguarda-o contra o arbítrio do Poder Público e o protege economicamente contra as exigências do ente público e dos prejuízos no caso de extinção do vínculo contratual. Se assim não fosse, o próprio Estado não encontraria ninguém que quisesse contratar com ele. Essa proteção poderá ser encontrada, por exemplo, no art.65, $\S 6^{\circ}$ da Lei Federal n. ${ }^{\circ} 8.666 / 93$, que assim dispõe:

Art.65. [....]

$\S 6^{\circ}$ Em havendo alteração unilateral do contrato que aumente os encargos do contratado, a Administração deverá restabelecer, por aditamento, o equilíbrio econômico-financeiro inicial. [Sublinhou-se]

\section{DA CLÁUSUlA REBUS SIC STANTIBUS À TEORIA DA IMPREVISÃo}

É mais comum do que se possa imaginar que um fato torne impossível a manutenção daquilo que se estabeleceu no contrato, acarretando às partes a adequação das regras aos eventos supervenientes.

Quando se busca estudar o instituto da imprevisão, se faz necessário uma "volta no tempo", para que se possa entender passo a passo o seu surgimento, e, conseqüentemente, a sua evolução ao longo dos anos. A razão do seu surgimento pode ser atribuída ao fato de que a consciência de todo homem que reflete postula a exigência de um princípio regular, superior às contingências, que se encarregue de definir a harmonia social na sua essência e indicar os meios de atingi-la:

O estudo da moderna Teoria da Imprevisão tem-se revelado através dos tempos atraente, cativante e desta forma sempre se revestiu de inovação e é certo que a novidade foi continuamente uma proposição encantadora, tormentoso problema de inacessível simpatia do homem, a ponto de aspirar que retrocedam os ponteiros do relógio das obras humanas, para que nelas se crie crosta, como alça de mira que arremesse nos faustos da história, o seu feito pessoal. (Oliveira, 1991, p.31)

Como já abordado, assim como se possibilita às partes escolher o conteúdo da avença, e até mesmo o modelo de contrato a ser celebrado, é imposto a cada contraente a sujeição aos seus termos.

A força obrigatória dos contratos fundamenta-se na regra de que o contrato faz lei entre as partes, que recebe a denominação clássica de pacta sunt servanda, determinando que os contratos devam ser cumpridos. 
No entanto, para a correta execução das obrigações contratuais exige-se, muitas vezes, que aquelas condições inicialmente constatadas perdurem até a extinção regular do acordo, que se dá mediante o cumprimento por ambas as partes daquilo que lhes cabia na avença. Os infortúnios, embora sejam imprevisíveis no seu momento, são claramente previsíveis na sua existência, isto é, não se sabe quando algo pode acontecer (como por exemplo uma tempestade), mas se pode cogitar da possibilidade do mesmo subsistir.

Situações podem existir que impossibilitem, total ou parcialmente, uma das partes no regular cumprimento do que fora acordado inicialmente, tornando tal prestação excessivamente onerosa para qualquer dos contratantes. Deve-se, assim, resguardar a parte prejudicada, garantindo-lhe meios suficientemente capazes de restabelecer o equilíbrio econômico-financeiro do contrato em questão, o que por si só já relativizaria o princípio da obrigatoriedade dos contratos. E é justamente nessa seara que há a atuação da Teoria da Imprevisão.

Por muitos anos, pela influência, sobretudo dos tribunais eclesiásticos, admitiu-se pacificamente, como subentendida nos contratos que tivessem dependência do futuro, a chamada cláusula rebus sic stantibus ${ }^{4}$. A partir de tal cláusula, nos contratos de trato sucessivo ou a termo, o vínculo obrigatório se entendia subordinado à continuação daquele estado de fato vigente ao tempo da estipulação.

Contudo, em que pese o conteúdo oriundo de tal preceito, a cláusula $s u b$ examine passou anos no mais completo esquecimento, ressurgindo especialmente após a Primeira Grande Guerra Mundial, e os movimentos sociais que assolavam a época, como abordados na introdução do presente estudo. Durante esse período, houve profundas alterações na base contratual, causando forte impacto nas relações contratuais de longo prazo, celebradas anteriormente ao grande conflito. $\mathrm{Na}$ França, assim, procurando solucionar os problemas surgidos oriundos da guerra, foi editada a chamada Lei Faillot. A partir desse instrumento, garantiuse que os contratos firmados desde $1^{\circ}$ de agosto de 1914 , afetados por situações imprevisíveis, pudessem ser resolvidos. Tal mandamento legal ressuscitou a antiga cláusula rebus sic stantibus, esquecida com o passar dos séculos, que serve como fundamento para a Teoria da Imprevisão, objetivo desse estudo. Tal cláusula estipulava que nos contratos de trato sucessivo ou de execução diferida, as condições existentes no momento da celebração do pacto deveriam permanecer até o fim do vínculo obrigacional.

${ }^{4}$ A denominação dessa cláusula resulta de uma abreviação da norma: contractus qui habent tractum succesivum et dependentiam de futuro rebus sic stantibus intelliguntur. 


\subsection{A FINALIDADE PRECÍPUA DA IMPREVISÃo}

Atualmente, a Teoria da Imprevisão possibilita aos operadores do direito a revisão de contratos cujas prestações se protraem no tempo, sempre que novas circunstâncias alterem de maneira exagerada a situação de fato existente à época em que foi assinado o contrato, de forma a tornar extremamente onerosa a execução da avença para uma das partes contraentes.

Seguindo os ensinamentos de Donnini (2001), a Teoria da Imprevisão teria como objetivo maior possibilitar a revisão contratual, e não, sua resolução, como alguns podem achar. Isso não quer dizer, contudo, que a parte lesada não possa pleitear a resolução do pacto, pois se a continuidade lhe for absolutamente insuportável nada obsta a opção por essa via. Todavia, deve-se priorizar a manutenção do contrato, que nessas situações pode ser conquistada mediante a reestruturação da balança econômico-financeira do acordo. Seria uma busca por mecanismos que tornem as prestações suportáveis e, acima de tudo, "cumpríveis".

Invoca-se a aplicação da Teoria da Imprevisão com o escopo de impedir que certas circunstâncias imprevisíveis, subseqüentes à formação do pacto, prevaleçam, tornando-o extremamente oneroso, inviabilizando a um dos pactuantes a sua fiel adimplência. Portanto, nessas relações deve prevalecer o bom senso, ao ponto de não imputar à parte adversa uma situação que lhe reduza todas as suas possibilidades. Sua invocação consubstancia uma forma de tornar relativo o absolutismo da regra pacta sunt servanda, abordada no capítulo precedente.

Destarte, a Teoria da Imprevisão pode ser concebida como uma espécie de remédio jurídico a ser empregado em situações de anormalidade contratual, tendo em vista fenômenos que ocorrem no campo extracontratual, dando origem a uma dificuldade excessiva de adimplemento, de sorte a fazer nascer uma lesão que poderá causar prejuízos irremediáveis àquele que se disponha a cumprir a obrigação assumida.

Ex positis, pode-se aduzir que tal teoria é, acima de tudo, um remédio jurídico incidente em situações extracontratuais aplicável excepcionalmente, destinandose à revisão ou, em casos extremos, à extinção da avença. Para a sua aplicação há de ser identificado como elemento principal o acontecimento imprevisível, considerado este como aquele situado fora do campo de percepção das partes. Esse acontecimento deverá trazer profunda alteração na base negocial, acarretando uma dificuldade extrema no cumprimento da prestação.

É concedida ao juiz a faculdade de rever o contrato sempre que eventos imprevisíveis modificarem profundamente as circunstâncias em que o vínculo obrigacional havia se formado, acarretando o desequilíbrio bem como a onerosidade excessiva. 
Essa teoria visa, portanto, a flexibilização do princípio da intangibilidade contratual e busca o restabelecimento da comutatividade, ou seja, o equilíbrio das prestações, por intermédio de intervenção judicial que tem por finalidade a revisão do contrato. (Mereniuk, 2006, p.240)

\subsection{A MORAL E A BOA-FÉ COMO FUNDAMENTOS DA IMPREVISÃO}

A moral e a boa-fé são elementos que devem reger toda e qualquer relação contratual. A moral está diretamente ligada aos bons costumes, a adoção de condutas conforme à justiça e à honestidade. Exigir que os convenentes atuem de acordo com a moral, é exigir, no mínimo, um comportamento decente, respeitador de determinados preceitos.

O credor não deve utilizar dos seus direitos inerentes à obrigação assumida de forma a reduzir as possibilidades da parte adversa. Deve haver sempre um sentimento de extrema justiça, desde o momento da celebração da avença, até o seu cumprimento. A exigência de equidade nas prestações assumidas tem esteio na própria moral. A satisfação absoluta exige o respeito fiel das convenções nas condições fixadas.

A boa-fé, por sua vez, deve ser invocada em todas as relações humanas. $\mathrm{Na}$ seara contratual, aplica-se a boa-fé a todas as espécies, sendo considerada essencial para a validade dos contratos. $\mathrm{O}$ respeito à fé prometida não é só uma necessidade decorrente de princípios, como por exemplo, o da segurança jurídica, ou da supremacia da ordem pública.

A boa-fé e a moral são elementos que reforçam a idéia que um contratante não pode se valer da ocorrência de um fato imprevisível que tenha afetado profundamente as condições pactuadas, para enriquecer ilicitamente, e assim submeter à parte contrária a condições de extrema onerosidade. Não se podem prever todas as situações durante o iter contratual. Toma-se, então, a boa-fé e a moral como uma ferramenta de restabelecimento das condições avençadas, como forma de buscar a melhor maneira de cumprir aquilo que fora acordado.

\subsection{PACTA SUNT SERVANDA X REBUS SIC STANTIBUS}

Tanto o pacta sunt servada, como a cláusula rebus sic stantibus, que anteriormente eram considerados de forma isolada, hoje em dia são concebidos como correlatos e incentivadores diretos para a celebração de contratos.

É obvio que não haveria qualquer razão que ensejasse a celebração de contrato se não houvesse mecanismos eficazes que buscassem assegurar o cumprimento das obrigações assumidas. Em contrapartida, devem-se garantir meios suficientemente idôneos que protejam as partes contra certos eventos exógenos à relação contratual que afetem profundamente os termos do acordo, 
evitando que um dos contratantes sucumba ao ponto de não conseguir cumprir com suas obrigações.

Refere-se aqui ao princípio do pacta sunt servanda e da cláusula rebus sic stantibus, que atuando conjuntamente influenciam no adimplemento obrigacional.

Se é certo que o contrato faz lei entre as partes (princípio do pacta sunt servanda), não é menos correto que os fatos que surgem à margem da lei devam ser tratados também de forma diferenciada. Já que não existe a possibilidade de se prever todas as situações, é preciso utilizar equilibradamente o bom senso para buscar solucionar determinadas situações que por motivos externos à convenção, tenham-na afetado consideravelmente.

Partindo desse ponto, se se considerar como definitivamente aceito que o benefício contratual deve atingir ambas as partes, ou seja, não se pode admitir que haja benefícios somente a um dos convenentes em detrimento da parte adversa, teremos que nos render à evidência irrefutável de que diante da ocorrência de eventos que gravitam em plano da excepcionalidade, supervenientes à celebração do vínculo contratual, para qual nenhuma das partes tenha contribuído, ter-se-á em mãos uma vicissitude que merecerá uma decisão fundada numa exceção. Nessa caso, se estará invocando um juízo de imprevisibilidade, como remedium iuris, para solucionar situações extravagantes.

A segurança pregada pelo pacta sunt servanda não pode ser mais considerada um princípio absoluto, em face justamente da invocação do preceito provindo da cláusula rebus sic stantibus, que permite a ruptura das convenções, uma vez verificando que, na sua execução, pela mudança das condições inicialmente existentes, um dos contratantes possa levar o outro à ruína.

Comprova-se a harmonização dos princípios sub examen, que em momento algum conflitam ou se chocam, direcionados para um mesmo fim: a aplicação de uma justiça comutativa.

Borges (2002, p.142), nesse sentido, aduz brilhantemente:

Então, à luz da boa-fé e da equidade fundamentos indispensáveis em todas as relações jurídicas , é suficiente a conjugação das duas expressões, com simples acréscimo da conjunção adversativa latina sed. Neste caminhar, teríamos: pacta sunt servanda sed rebus sic stantibus, que equivale a "o contrato faz lei entre as partes, mas desde que mantidas as condições iniciais da contratação".

\section{REVISÃo CONTRATUAL}

O escopo principal do contrato é ser cumprido. Não há motivos para a manutenção prolongada do vínculo contratual. As partes convencionam o acordo, combinam o adimplemento de suas obrigações, e, subseqüentemente, extingue-se 
o pacto. Segundo Gonçalves (2004, p.154), “os contratos, como negócios jurídicos em geral, têm também um ciclo vital: nascem do acordo de vontades, produzem os efeitos que lhe são próprios e extinguem-se".

Alcançada a finalidade precípua que ensejou a criação da relação obrigacional, extingue-se a avença. Ele nasce para um dia ser extinto, o que denota seu caráter temporal:

Ao contrair uma obrigação, ao engendrar um contrato, as partes têm em mira, desde o início, a possibilidade de seu término, ainda que não se fixe a priori um prazo para o cumprimento. $\mathrm{O}$ vínculo contratual, quando o bojo de suas obrigações atinge o desiderato, desfaz-se. (Venosa, 2004, p. 513).

Contudo, podem sobrevir fatos que inviabilizem o cumprimento do contrato por motivos alheios à vontade das partes, ocorrendo o que se chama de inexecução contratual. Caso essa inexecução seja total, resolve-se o contrato. Agora, caso haja a possibilidade de prosseguir com a avença, reajusta-se os termos do contrato reestruturando as condições dantes pactuadas. Isso é o que acontece no caso da revisão contratual por onerosidade excessiva, onde o princípio consagrado do pacta sunt servanda cede lugar ao princípio da revisão contratual.

A revisão contratual encontra fundamento na cláusula rebus sic stantibus, que se considera ínsita aos contratos de trato sucessivo ou de execução diferida. Através da cláusula em destaque se presume que as condições acertadas inicialmente vão perdurar durante todo o contrato, até o momento da sua execução.

Como explanado, a cláusula em questão deu origem a chamada Teoria da Imprevisão, objeto do presente estudo. A aplicação dessa Teoria teria a função de proporcionar a revisão contratual, buscando o restabelecimento ou a continuidade do equilíbrio nas relações negociais. Nos dizeres de Fonseca:

Procura ela investigar, em síntese, se é justo, e em que termos, admitir a revisão ou resolução dos contratos, por intermédio do juiz, pela superveniência de acontecimentos imprevistos e razoavelmente imprevisíveis por ocasião da formação do vínculo, e que alterem o estado de fato no qual ocorreu a convergência de vontades, acarretando uma onerosidade excessiva para um dos estipulantes. (1958, p.19).

\subsection{REQUiSITOS PARA A APLICAÇÃO DA TEORIA DA IMPREVISÃo}

É importante consignar que não basta a simples vontade para a aplicação da Teoria da Imprevisão. Mister se faz a observância de uma série de requisitos. Quando se trata da aplicação da Teoria aos contratos administrativos, exige-se uma maior cautela. A liberdade nessa modalidade contratual é bem mais mitigada, em face da supremacia do interesse público. 
Segundo os ensinamentos de Borges (2002), os pressupostos considerados indispensáveis para a aplicação da Teoria da Imprevisão são: execução diferida, imprevisibilidade, ausência de estado moratório, lesão virtual, essencialidade, inimputabilidade, excessiva onerosidade e extrema vantagem. Passa-se agora a discorrer sobre cada um dos pressupostos mencionados.

A Teoria da Imprevisão deve ser aplicada àqueles contratos de execução diferida $^{5}$ ou trato sucessivo ${ }^{6}$, não encontrando espaço nos contratos de execução imediata ou instantânea ${ }^{7}$.

A restrição aos pactos de execução imediata é perfeitamente compreensível e aceitável, com base na exigência de que para o surgimento ou não do fenômeno de exceção é indispensável o decurso de um certo tempo, que os de execução imediata não possuem. Neste contexto as partes cumprem suas respectivas obrigações ao mesmo tempo. (Borges, 2002, p.299).

Em relação à imprevisibilidade, essa pode ser identificada, inicialmente, por exclusão. Se a previsibilidade decorre a partir da identificação de um fato certo e provável, por via inversa, o fato incerto e improvável representaria a imprevisão. No caso de um fato inexistente no momento da celebração da avença, vindo a ser revelado, contudo, mais tarde, deve ser considerado imprevisível, ensejando pedido de revisão contratual. Nesses casos, o elemento imprevisível produz efeitos consideravelmente tão fortes que acabam comprometendo a base negocial do pacto.

Como consignado em momento anterior, os infortúnios, embora sejam imprevisíveis no seu momento, são claramente previsíveis na sua existência, isto é, não se sabe quando algo pode acontecer (como por exemplo, uma tempestade), mas sabe-se da possibilidade do mesmo subsistir. Além da necessária ocorrência de evento superveniente e alheio à vontade das partes, faz-se necessário que ele modifique as condições inicialmente acordadas de modo que haja uma extrema dificuldade de adimplemento para uma, ou ambas, as partes.

O terceiro pressuposto proposto por Borges para a aplicação da Teoria da Imprevisão é a ausência do estado moratório. Situações podem existir que, mesmo presente todos os requisitos necessários para a aplicação da Teoria da Imprevisão, mesmo assim não poderá haver sua invocação. Isso se dá quando a obrigação a ser cumprida se encontrar em estado moratório, isto é, a obrigação já tenha atingido e ultrapassado a data de cumprimento. Dessa forma, aquele que procura

\footnotetext{
${ }^{5}$ Contratos de execução diferida são aqueles que devem ser cumpridos através de um só ato, mas em momento futuro. $\mathrm{O}$ adimplemento da obrigação não se dá logo após a formação do vínculo contratual, mas a termo.

${ }^{6}$ Contratos de trato sucessivo, ou também chamados de execução mediata, são os cumpridos mediante prática de atos reiterados, como ocorre nos casos de compra e venda a prazo.

${ }^{7}$ Contratos de execução imediata ou instantânea são aqueles que se consumam em um só ato, sendo cumpridos logo após a formação do vínculo, como exemplo, os casos de compra e venda à vista.
} 
abrigo na Teoria da Imprevisão para excepcionar a regra do pacta sunt servanda deverá fazer antes do vencimento obrigacional. Importante deixar claro que isso é a regra. A exceção se dá nos casos de a mora surgir após a imprevisibilidade. Nessa hipótese, a superveniência de algum fato alterador da base negocial surge antes da ocorrência do estado moratório, o que mantém o direito do devedor de pedir a modificação dos termos da avença.

O quarto pressuposto é a lesão virtual. A lesão virtual é também conhecida na doutrina como lesão subjetiva ou iminente. A presença desse requisito é indispensável para que se completem as exigências necessárias para a invocação da Teoria em tela. A lesão virtual pode ser configurada naqueles casos em que surge uma dificuldade extrema de adimplemento. Vale ressaltar que a lesão aqui tem que ser iminente, potencial, ou seja, que ainda não tenha ocorrido.

O quinto pressuposto defendido por Borges é a presença da essencialidade. A essencialidade é identificada quando a ocorrência dos fatos atinjam àqueles elementos considerados essenciais no pacto. Assim, exigir o fiel cumprimento das obrigações assumidas em um contrato que tenha a sua base negocial profundamente afetada, seria atentar contra os princípios da boa-fé e da equidade.

$\mathrm{O}$ sexto requisito acima relacionado é o concernente à inimputabilidade. Segundo Borges:

Há de existir, de forma inconteste, a negativa de autoria do fato alterador das circunstâncias em que as partes fundaram suas vontades de contratar, gerador da lesão virtual ou extinção da base negocial, por via de ação ou omissão atribuível àquele que dela pretenda se valer. (2004, p.321)

Destarte, o acontecimento alterador da estrutura contratual não pode ter sido provocado por quem invoca a aplicação da imprevisibilidade. Ocorrido o evento modificador, sendo esse reconhecidamente imprevisível, não poderá haver imputabilidade desse fato àquele que pretende fazer uso desse remédio de exceção.

E por último, Borges enumera como pressuposto de aplicação da Teoria da Imprevisão a existência de uma excessiva onerosidade e extrema vantagem. Faz-se necessário que a superveniência de fato imprevisível e alheio à vontade das partes altere profundamente as bases do negócio jurídico celebrado, ocasionando uma onerosidade excessiva para uma das partes, em detrimento de uma vantagem exagerada para a parte adversa. São requisitos que devem ser observados concomitantemente.

\subsection{A TEORIA DA IMPREVISÃO E OS CONTRATOS ADMINISTRATIVOS}

Nos contratos administrativos, como já consignado, há a prevalência de uma série de prerrogativas por parte da Administração Pública que tornam a aplicação da Teoria da Imprevisão mais mitigada. Diferentemente do que ocorre 
nas relações contratuais celebradas entre particulares, a liberdade de atuação sofre considerável atenuação.

Convém trazer à baila o que preconiza Cunha:

[....] apesar de estar pacificada a aplicação da teoria da imprevisão, vale ressaltar que contratar com o Estado detentor de múltiplas possibilidades da intervenção não é como contratar com um agente privado. Afinal, o contrato administrativo é tipificado pela participação da administração na relação jurídica com supremacia de poder para fixar as condições iniciais do ajuste, e conseqüentemente, a faculdade de impor as chamadas cláusulas exorbitantes ao direito comum. (1995, p.43-44)

Destarte, semelhantemente como ocorre naqueles modelos contratuais regidos por normas eminentemente de Direito Privado, nos contratos administrativos poderá ser invocada a aplicação da Teoria da Imprevisão quando, no curso do contrato, sobrevierem eventos excepcionais e imprevisíveis que subvertam a equação econômico-financeira do pacto. Assim, durante a execução de contratos, em especial daqueles de longa duração, podem ocorrer alterações econômicas imprevisíveis, tornando inviável ao particular executar o contrato nas condições originariamente previstas. Executar a prestação nos exatos termos inicialmente previstos acarretaria sua ruína, com o enriquecimento correspondente da outra parte.

O elemento característico da Teoria da Imprevisão nos contratos administrativos é a presença da chamada álea econômica, que, pela sua natureza extraordinária, excede os riscos normais admitidos nesse negócio jurídico.

Carvalho Filho (2006, p.178) preconiza, ipsis litteris,

O efeito da teoria da imprevisão calca-se em duas vertentes. Se a parte prejudicada não puder cumprir, de modo nenhum, as obrigações contratuais, dar-se-á a rescisão sem atribuição de culpa. Se o cumprimento for possível, mas acarretar ônus para a parte, terá esta direito à revisão do preço para restaurar o equilíbrio rompido. [Grifo do autor].

Para se identificar a extraordinariedade da álea econômica, é necessária uma análise segundo um prisma da razoabilidade.

Quanto à álea ordinária e extraordinária, como visto acima, a imprevisão só é aplicada a essa última. Colaciona-se os ensinamentos de Justen Filho alusivos à extraordinariedade da álea contratual.

A distinção entre ordinariedade e extraordinariedade se relaciona com a probabilidade da ocorrência dos eventos. $\mathrm{O}$ critério diferencial não é a mera possibilidade do evento, o que tornaria inútil tal distinção: todo evento possível seria previsível e, por isso, integraria a álea ordinária. Logo, comporiam a álea extraordinária apenas os eventos impossíveis, os quais nunca ocorreriam por sua própria definição. (2006, p.304). 
No Direito Privado, há a prevalência da disponibilidade da vontade das partes. Dessa maneira, as questões relacionadas à manutenção do equilíbrio dos contratos encontram soluções mais fáceis do que as verificadas no âmbito público. Em nome da cláusula rebus sic stantibus, verificando-se fatos imprevisíveis e que afetem o equilíbrio econômico-financeiro do contrato, deve ser promovida a recomposição de modo a restabelecer o seu equilíbrio inicial.

Já nos contratos administrativos, os mecanismos e instrumentos de reestruturação dos termos da avença devem estar expressamente previstos nos instrumentos contratuais e em lei. A grande dificuldade consiste exatamente no fato de que é praticamente impossível aos contratos e à lei estabelecerem as situações em que ocorrerá o desequilíbrio contratual e, sobretudo, indicarem as soluções a serem adotadas para recompor esse equilíbrio.

Segundo Furtado,

[.... admitir a aplicação da teoria da imprevisão aos contratos administrativos fora das circunstâncias definidas em lei, vale dizer, aceitar a recomposição de preços nos contratos a todo tempo e modo, na hipótese de o contratante apenas demonstrar alterações na relação econômicofinanceira, seria negar qualquer sentido ao instituto da licitação e premiar o licitante que, por má-fé ou inépcia empresarial, apresentou proposta que, com o tempo, revelou-se antieconômica. (2007, p.378).

O art.65, inciso II, “d”, da Lei Federal n. ${ }^{\circ}$ 8.666/93 vem garantindo a possibilidade da aplicação da Teoria da Imprevisão aos contratos administrativos. Senão note-se:

Art.65 Os contratos regidos por esta Lei poderão ser alterados, com as devidas justificativas, nos seguintes casos:

I omissis

II por acordo das partes:

$[\ldots$.

d) para restabelecer a relação que as partes pactuaram inicialmente entre os encargos do contratado e a retribuição da Administração para a justa remuneração da obra, serviço ou fornecimento, objetivando a manutenção do equilíbrio econômico-financeiro inicial do contrato, na hipótese de sobrevirem fatos imprevisíveis, ou previsíveis, porém de conseqüências incalculáveis, retardadores ou impeditivos da execução do ajustado, ou ainda, em caso de força maior, caso fortuito ou fato do príncipe, configurando área econômica extraordinária e extracontratual.

Segundo o dispositivo acima, para que haja a correta aplicação da Teoria da Imprevisão aos contratos administrativos, mister se faz também a observância de alguns requisitos, a saber: a superveniência de fatos imprevisíveis alheios à vontade das partes, ou no caso de previsibilidade, que tenham conseqüências 
incalculáveis; que tais fatos sejam estranhos à vontade dos pactuantes; sejam os fatos inevitáveis; e que afetem profundamente o equilíbrio contratual.

Apesar dos contratos administrativos estarem salvaguardados por uma série de prerrogativas inerentes ao ente público, não se pode, sob o pretexto de garantir a efetivação de princípios como o da supremacia do interesse público, ou da continuidade do serviço público, submeter o contratante a situações degradantes. O elemento boa-fé deve prevalecer durante todo o iter negocial, não podendo o particular suportar um ônus excessivamente oneroso por algo que não lhe pode ser imputado. Assim, em havendo alterações profundas na base contratual, é garantido à parte lesada recorrer ao Judiciário para a reestruturação dos termos da avença. Essa garantia é decorrente da própria lei, como se pode subtrair do dispositivo supramencionado.

É importante consignar, por fim, que o interesse em reestruturar a equação econômico-financeira do contrato é da Administração Pública. Caso o contratado tivesse que arcar com todas as conseqüências oriundas da relação negocial, haveria a necessidade de se formular propostas bem mais onerosas para o ente público. Torna-se muito mais vantajoso para o Estado contratar a partir das propostas mais econômicas, e, no caso da superveniência de algum infortúnio inimputável às partes, haver divisão dos encargos originados daí.

É natural que, em uma relação contratual, o particular procure o lucro. Contudo, a Administração Pública, diferentemente, tem por escopo maior a satisfação do interesse coletivo. Destarte, o ente público deve atuar em seus contratos de forma a respeitar os princípios basilares que regem as relações contratuais, não submetendo o particular a situações degradantes em detrimento de benefícios econômicos suplementares.

\section{[i. CONSIDERAÇões FINAIS}

A Teoria da Imprevisão surge como um mecanismo eficiente para recompor a base negocial. Seja servindo de fundamento para a revisão contratual, mantendo válido o contrato, ou, ainda, resolvendo o negócio jurídico, desfazendo o vínculo inicialmente firmado.

É claro que quando se trata daquela espécie de contratos firmados somente entre particulares, regidos por normas eminentemente de Direito Privado, as partes possuem uma certa liberdade para atuarem dentro da relação. A disponibilidade dos bens em questão se torna mais evidente. A invocação da Teoria da Imprevisão se torna mais fácil, mais livre, sendo inúmeras as possibilidades de se utilizar dessa ferramenta. Agora, no que concerne aos contratos administrativos, entendidos esses como aqueles em que em um dos pólos da relação contratual se encontra a Administração Pública, atuando na qualidade de ente público, com todas as 
prerrogativas que lhe são pertinentes, tendo em vista sua condição de superioridade na relação, a situação sofre severas mudanças.

Nessa modalidade contratual, a liberdade de atuação das partes sofre grande mitigação. E isso ocorre por diversos fatores. Dá-se, por exemplo, porque a Administração Pública é regida por uma série de princípios, como o da supremacia do interesse público sobre o interesse particular, o princípio da continuidade do serviço público, dentre outros. Destarte, quando o particular se envolve em uma relação negocial com o Estado, deve respeitar uma série de normas, que na grande maioria das vezes, privilegiam o ente público.

A aplicação da Teoria da Imprevisão nas avenças administrativas só deve ser permitida naqueles poucos casos em que a própria lei expressamente consente. Não se pode deixar ao mero alvedrio das partes a liberdade de decidirem sobre esses pontos. Se todo contrato tem que cumprir a sua função social, com os contratos administrativos não é diferente. Há ainda um agravante, que é justamente os efeitos produzidos pelos contratos, que no caso dos contratos administrativos atinge até mesmo aqueles que não participaram diretamente do negócio jurídico. A liberdade nos contratos regidos por normas de Direito Público sofre considerável atenuação, tudo isso em detrimento de princípios de ordem cogente, que quando comparados com os interesses particulares, devem prevalecer.

\section{REFERÊNCIAS}

ANGHER, Anne Joyce (org.). Vade mecum acadêmico de direito. 4. ed. São Paulo: Rideel, 2007.

BORGES, Nelson. A teoria da Imprevisão no direito civil e no processo civil. São Paulo: Malheiros, 2002.

CARVALHO FILHO, José dos Santos. Manual de direito administrativo. 15. ed. Rio de Janeiro: Lúmen Júris, 2006.

CUNHA, Thadeu Andrade da. A teoria da imprevisão e os contratos administrativos. Revista de direito administrativo. N. ${ }^{\circ} 201$ jul./set. 1995.

DONNINI, Rogério Ferraz. A revisão dos contratos no código civil e no código de defesa do consumidor. 2. ed. São Paulo: Saraiva, 2001.

FONSECA, Arnaldo Medeiros da. Caso Fortuito e teoria da imprevisão. 3. ed. Rio de Janeiro: Forense, 1958.

FURTADO, Lucas Rocha. Curso de direito administrativo. Belo Horizonte: Fórum, 2007.

GAGLIANO, P. S.; PAMPLONA FILHO, R. Novo curso de direito civil: contratos. 2. ed. Vol. IV. Tomo 1. São Paulo: Saraiva, 2006. 
GONÇALVES, Carlos Roberto. Direito civil brasileiro: contratos e atos unilaterais. Vol.III. São Paulo: Saraiva, 2004.

JUSTEN FILHO, Marçal. Curso de direito administrativo. 2. ed. São Paulo: Saraiva, 2006.

MERENIUK, Ruy Orlando. Teoria da imprevisão: a doutrina Keynesiana frente ao código civil. Curitiba: Juruá, 2006.

MONTEIRO, Washington de Barros. Curso de direito civil: direito das obrigações $2^{a}$ parte. 34. ed. Vol. 5. São Paulo: Saraiva, 2003.

MELlO, Celso Antônio Bandeira de. Curso de direito administrativo. 19. ed. São Paulo: Malheiros, 2005.

OLIVEIRA, Anísio José de. A teoria da imprevisão nos contratos. 2. ed. São Paulo: Leud, 1991.

PEREIRA, Caio Mário da Silva. Instituições de direito civil: contratos. 11. ed. Vol.III. Rio de Janeiro: Forense, 2004.

RODRIGUES JR., Otávio Luiz. Revisão judicial dos contratos: autonomia da vontade e teoria da imprevisão. São Paulo: Atlas, 2002.

SANTOS, Eduardo Sens. O novo código civil e as cláusula gerais: exame da função social dos contratos. Revista brasileira de direito privado. N. ${ }^{\circ} 10$, abr/jun. São Paulo: RT, 2002.

VENOSA, Silvio de Salvo. Direito Civil: teoria geral das obrigações e teoria geral dos contratos. 2.ed. Vol. II. São Paulo: Atlas, 2004.

\section{SÍtIOS ELETRÔNICOS}

www.adagio.com.fr/consomed/FRCO0444.HTM. <acesso em 17/07/07>

www.redetel.gov.ar

$<$ acesso em 17/07/07>

www.direzioneamministrativa.unile.it

$<$ acesso em 19/0707>

\section{THE THEORY OF IMPREDICTMENT AND PUBLIC CONTRACTS}

Abstract: When the State fuctions as subject of a contractual relation, it has certain prerrogatives inherent to its supremacy condition. Thus, the contract according by the rules of Public Law should be analyzed more cautiously, as this contractual mode cannot be freely used by those specific institutes widely applied to the agreements settled among private parties and conducted 
with a private character. The guiding principles of these typical private contracts, should be dealt with caution, having in mind the principles that conduct the roles of Public Administration, such as the principle of supremacy of the public interest and also the principle of the continuity of the public service. The public interest should always prevail above the private interest serving as a base to rule the relations among the public and third parties.

Key words: Public Management. Supremacy. Administrative contracts. 